\title{
From the Aim of Creating More Habitable Cities to Typification
}

\author{
H. Ceren Duman and Tülin Vural Arslan
}

\begin{abstract}
Rapid urbanisation in all over the world in the last fifty years has affected people's perceptions of life and raised their expectations with regard to quality of life. In this regard, especially raising the level of quality of life especially in housing environments has become the important priorities of governments' planning policies. In relation to this development, in Turkey as an alternative solution to the problem of housing stock that could not keep up with the speed of haphazard urbanisation, the Collective Housing Administration(TOKI) was created. With an aim of making cities more habitable, TOKI is rapidly carrying out numerous projects all over the country. However, during the process of this rapid development homogenised cities are being created with the disregard for local values. In the scope of this study, the typification, on urban, neighbourhood and housing unit scales, resulting from the housing environments produced by TOKI will be discussed.
\end{abstract}

Index Terms-Typification, quality of life, mass housing, Toki, Turkey.

\section{INTRODUCTION}

Since 1950s in Turkey, - along with the growing industrialization and changing agricultural policies-, internal migration and rapid population growth has begun to change the urban and social structures of Turkish cities. Many of the Turkish cities which had the unique examples of traditional settlement areas in their centers have been invaded by squatter settlements and illegal housing areas. This rapid urbanisation requires new solutions for preserving the characteristics of Turkish cities on the one hand, on the other hand providing more liveable environments for the new inhabitants of the cities.

The rising expectations from the quality of life in Turkish cities have been the pushing factor of seeking for the new national urban policies. As part of these policies, Housing Development Administration of Turkey (Toplu Konut Idaresi Baskanligi-TOKI) was established in 1984.

One of the main target of this institution is improving the quality of life in squatter settlements in Turkish cities and it is explained as follows "to reconstruct the illegally occupied and underdeveloped (in terms of lacking basic urban services, like adequate water, proper sanitation, transportation etc.) squatter regions through clearing of such regions and to rehabilitate those areas by constructing a modern, livable settlements with the provision of adequate shelter, sanitation, social facilities, better environment quality etc".

Although TOKI has a good ambition about improving the

Manuscript received December 31, 2014; revised May 4, 2015.

The authors are with the Uludag University, Faculty of Architecture, Department of Architecture Görükle, Bursa 16059, Turkey (e-mail: crndmn21@gmail.com, tulinv@yahoo.com). quality of life in Turkish cities, the outcome of its projects does not fulfil this scope. TOKI's typified planning concepts, which are far beyond taking into consideration of cultural, climatic and topographic differences of urban environments, has brought about a process of homogenization in Turkish cities. However, it is known that quality of life concept does not only including the renovation of infrastructure systems or creating more liveable environments, it also includes social issues, like cultural memory, identity and also feeling belong to somewhere. In the scope of work, the typification process of TOKI in master decisions of site plan, mass organizations and fronts decisions, floor plans are discussed with the examples of TOKI housing areas in different Turkish cities. In conclusion part, the importance of sustaining local identities while providing globalised environments is discussed.

\section{THE QuAlity OF LIFE CONCEPT}

The concept of quality of life is one which has come to the fore along with the development of modern life and the modernisation of humanity and which updates itself with changing conditions over time. The concept of quality of life has been approached in studies carried out in different fields of interest and from different directions. For this reason, many different definitions can be found. From among these definitions, the consensual view that can be put forward is: "Quality of life is the combined effect on public welfare of objective variables related to an individual's life with subjective variables shaped by an individual's own perception" [1].

WHO defines Quality of Life as individuals' perception of their position in life in the context of the culture and value systems in which they live and in relation to their goals, expectations, standards and concerns. This broad concept affected by the person's physical health, psychological state, level of independence, social relationships, personal beliefs and their relationship to salient features of their environment. [2].

\section{DECISIONS, LAWS AND REGULATIONS RELATED WITH THE EMERGENCE OF THE CONCEPT OF QUALITY OF LIFE IN THE WORLD AND IN TURKEY}

When today's social regulations are discussed, the general approach is the necessity for raising quality of life. With the effect of globalisation, these regulations, which define the destiny of a country, have come to the point where representative democracy can no longer be ensured and where decisions taken anywhere in the world also affect other 
countries. For this reason individual- and human-based aims have begun to replace national development aims. An aim has begun to be observed that sees the need for a multi-faceted evaluation of life quality and the need to approach human rights from the viewpoint of urbanisation policies and economic policies on a local and national level [3].

On the international platform, the importance of life quality in human life has been highlighted in many accepted documents. To mention some of these, in the third clause of the Universal Declaration of Human Rights, it is asserted that humans have the right to live in freedom and security, and in the twenty-fifth clause, that every person has the right to have a sufficient standard of living and to be assured in situations such as dwelling place and health care along with other necessary community services and in such cases as unemployment and illness [4].

In the UN Covenant on Civil and Political Rights, the duty was given to governments to take positive measures to ensure the right to life by the acceptance of freedom, justice and peace, as long as people can use their personal and political rights alongside their economic, social and cultural rights [5]. At the UN's Rio Summit on Environment and Development (1992), with the accepted Agenda 21 Resolution, progress was made towards international agreements that serve the benefit of all mankind and preserve the integrity of the global environment and development systems, and a number of principles were adopted by accepting that the world we live in is made up of interdependent parts. One of the principles stated that the sustainable development of mankind must be at the heart of the matter, and it was stressed that humans have the right to a healthy and plentiful life in communion with nature. Another principle states the necessity for cooperation in order to eradicate poverty and reduce the differences between standards of living in all countries and for all people, and to better meet the needs of people all over the world [6].

The International Environmental Strategy and Action Plan, whilst not having the legal force of a development plan or international programme, nevertheless bears an important quality as a basic policy document with regard to quality of life. The Plan, in the report prepared in 1998, defines quality of life as "the quality and quantity of factors that have positive effects on physical, spiritual, mental and cultural development, and the type and level of benefit from these factors". Work aimed at implementing the International Environmental Strategy and Action Plan in Turkey was begun on 8th May 1998 in a protocol signed by the State Planning Organisation's Undersecretaries and the Ministry. The aims stated during the preparation process of the International Environmental Strategy and Action Plan and formed within the framework of the action plan are as follows:

1) Improvement of quality of life;

2) Development of environmental consciousness and awareness;

3) Improvement of environment management;

4) Provision of sustainable economic, social and cultural development.

Among the strategic aims of the International
Environmental Strategy and Action Plan are quality of life; the increasing of targets like the facilitation of access to basic environmental infrastructures and services, reduction of exposure to environmental dangers to a minimum, provision of a better-quality environment for Turkish citizens, and improvement of life quality for approximately 20 million citizens living in slum areas [7].

The Integrated Urban Development Strategy and Action Plan, prepared for the years 2010-2023 by KENTGES, also contains aims in the direction of raising quality of life and living space. These aims are presented under the following headings:

1) To ensure sustainable spatial development in settlements, and to realise the production and supply of sustainable and diversified land and housing,

2) To ensure the development and rejuvenation of central business areas, subcentres and neighbourhood centres with sustainable policies,

3) To create a sustainable urban transport system,

4) To integrate urban infrastructure plans, projects and investments with spatial plans,

5) To ensure the even distribution of social reinforcement and services in settlements,

6) To develop open and green areas in spatial plans by system integration,

7) To ensure the protection of natural and cultural assets and values,

8) To ensure integrated urban renewal and recycling in social, cultural and economic proportions,

9) To reduce disaster and settlement risks,

10) To create safe settlements with a high quality of life and living space,

11) To protect and develop urban identity,

12) To create an environmentally-aware living area in cities. [8].

As far as this section, all criteria, principles and decisions related to the aforementioned quality of life are considered joint determiners of the subject.

\section{EMERGENCE OF TOKI IN TURKEY FOR RAISING THE QUALITY OF LIFE IN RESIDENTIAL AREAS}

All over the world, a number of decisions have been made aimed at raising quality of life for people to live better and healthier lives. It was intended that these decisions would be guaranteed by both national and international agreements and governments were given duties to behave in accordance with this. In Turkey, too, the rise in urbanisation brought to light an adequate and quality housing deficit suitable for every budget. For this reason, to meet the need for shelter, one of the basic needs of humans, an executive organ was required. At this point, the 1981 Collective Housing Law no. 2487 and later the Collective Housing Administration set up in 1984 came into use and began the housing mobilisation aimed at those unable to house themselves by their own means and on low incomes.

'The TOKI residences began under the name of council estates in the world and in our country became popular within the framework of different aims such as creating recycling areas for slums, producing housing for low-income 
groups and producing public buildings' [9]. TOKI, established within the scope of the Ministry of Public Works and Settlement, states its own working area and strategy as follows:

1) To discipline the housing market by ensuring the realisation of housing production within a certain model framework by alternative, innovative applications;

2) To prevent speculative developments by paying attention to matters such as quality, solidity and reasonable prices;

3) To pursue its activities throughout Turkey with determination and resolution with the basic aim of aiding the even distribution of the country's population over the country's geographical area.'

In accordance with the aims defined above, the mass housing implementations, carried out with the target of producing many dwellings at once and generally by being designed at one single centre, are unfortunately typifications with the tendency to standardise the concept of the need and quality to display differentiation on a local scale. At the same time the planning, carried out with consideration for cost, and in settlement areas chosen at a distance from the city centre, raises a question mark as to how far the mass dwellings carry out their duty as social dwellings. Their location far from the city centre, from resources such as work, health and transport, and from the core containing the city's history, harms the relationship formed with the city, and brings with it alienation from that place.

\section{EVAluATION OF “QUALITY OF LIFE” IN TOKI SETTLEMENT AREAS}

In Turkey in general, large-scale production carried out by TOKI has reached 633,336 residences. When the number of flats located in the residences and the accompanying number of households are taken into account, a significant percentage of Turkey's population lives in these residences. When production was being carried out on this scale, a large amount of research was carried out with the aim of raising quality of life and its corresponding user satisfaction.

In Turkey, the success of mass housing production is assessed by its quantity not by the quality of the environment that offer to its inhabitants. In design process, the effects of socio-cultural factors on spatial environments are generally neglected due to multiplicity and variety of the users. In addition to that, the intention about producing housing environments in a rapid way affects the selection of construction technology. From the viewpoint of construction technology and ease of achieving projects the selection of standard projects also brings typification with it. For this reason, the monotony and anonymity regarded as associated with this typification affects quality of life on an urban scale and on the scales of neighbourhood unit and residence.

\section{A. Typification in Urban Scale}

TOKI applied in different regions of Turkey, structures of a similar appearance have been built and settlements of a similar appearance have been created by neglecting features particular to local areas. Examples mostly situated far from city centres have not ensured a social or cultural environment for users and, with their undefined areas in the landscaping, have not provided a productive recreational area either.

Despite being situated in Turkey's varied climatic and geographical regions, the below examples (see Fig. 1), with their use of identical architectural language, have caused problems such as loss of natural climatisation and of urban memory.

The choice of location away from the city has brought about both a semantic and spatial alienation of these settlements from the city.

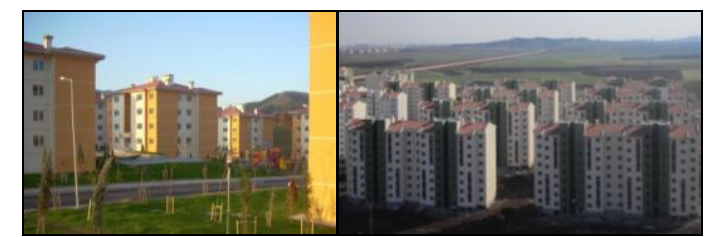

Bursa

Diyarbakır
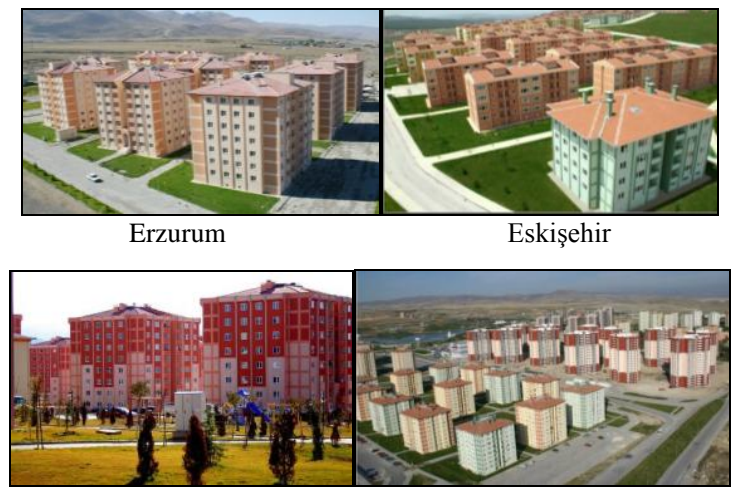

Sivas

Ankara

Fig. 1. Views from TOKI settlements from different cities of Turkey [10].

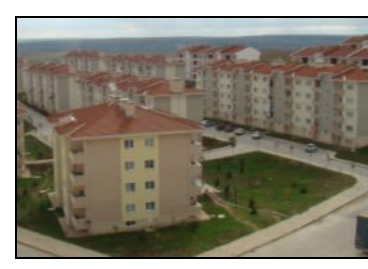

Eskişehir Odunpazı Toki



Sivas İmranlı Toki
Fig. 2. Views from TOKI's's residential areas [11], [12].

\section{B. Typification in Neighbourhood Scale}

As İlhan Tekeli has mentioned "It is clear that architecture, on the level of both the buildings and of the arrangement of spaces outside the buildings, is one of the items which make a contribution to quality of life", [3]. On the scale of neighbourhood environments in TOKI settlements (see Fig. 2), because of lack of consideration for social reinforcement areas, a weakening in social relations has a risen. When the contribution of architectural quality to life quality is considered, if we deal with architectural products on the level of the buildings, then the fact that the buildings are ugly or beautiful will affect not only the inhabitants of those buildings, but everyone in the surrounding area and those going out of the residence. Home owners in Turkey, while giving importance to the quality of the interior of their homes, remain indifferent to the areas of collective responsibility outside their homes. For this reason communal areas are turned into abandoned, polluted and unfinished areas. We can say that the same situation may be observed in TOKI 
settlement areas, from the viewpoint of both building quality and quality of the areas surrounding the buildings.

\section{Typification in Housing Unit Scale}

On the housing scale in TOKI, standard living areas are being created without any attention being paid to cultural differences (Fig. 3, Fig. 4). The structural limitations in the production process do not make it possible for vital transformation within the dwellings. In Turkey, healthy housing practices that should be at an optimum level are carried out at a minimum level. This situation has given rise to the creation of isolated islands of life which cannot integrate with the city, of homogenous, anonymous building blocks in which the concept of neighbourhood is removed and which can be seen anywhere in the country, and has triggered the situation where the users' expectation of their dwellings is merely that of a place where they can shelter after closing their doors.

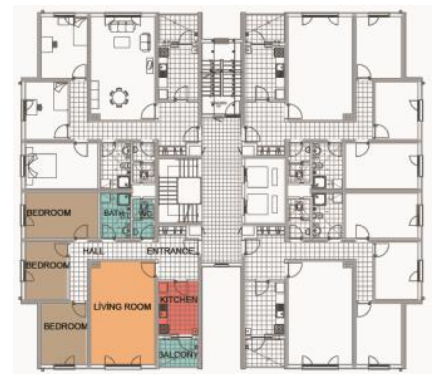

Diyarbakır C2 block B+Z+8 normal floor plan Fig. 3. TOKI's floor plans from different cities of Turkey [13].

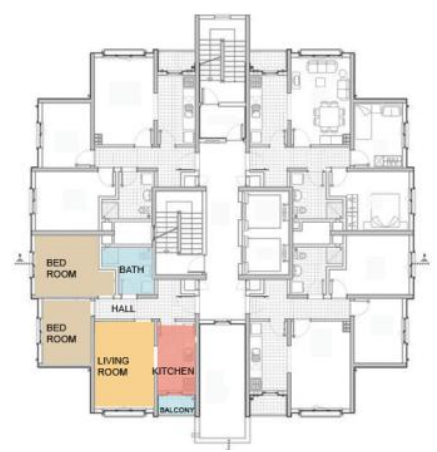

Bursa Gürsu normal floor plan

Fig. 4. TOKI's floor plans from different cities of Turkey [13].

\section{CONCLUSION}

TOKI Buildings, which were made with the aim of providing environments suitable for a high quality of life, in fact reduce quality to a degree on different scales. Users from low income groups can find comforts such as building technology and quality of material in their new residences that they did not have in their previous dwellings. On the other hand, the limited budgets set aside for mass housing production and the aim of saving time have minimised the use of facilities for ensuring quality.

The need for suitable projects to be carried out instead of typified ones has a risen. Only projects carried out on a local level can answer expectations aimed at local social, cultural and living habits. At the same time, by taking the climate, geographic conditions and materials of the area into account, the way will be paved for sustainable building design for a quality environment.

The realisation of architectural quality, as stated in reports like the Universal Declaration of Human Rights and the UN Covenant on Civil and Political Rights, is identified with people's quality of life and therefore their right to an honourable life. For this reason, in new housing, building and environmental design must be carried out regardless of income rate and with an equal approach and quality.

\section{REFERENCES}

[1] R. Marans, "Kentsel Yaşam Kalitesinin Ölçülmesi," (Evaluation of Urban Life Quality), (Trans. H. Turkoglu) Mimarlık 335, 2007.

[2] W. H. Instruments. (1997). Measuring Quality of Life. [Online] Available: http://www.who.int/mental_health/media/68.pdf

[3] İ. Tekeli, Gündelik Yaşam, Yaşam Kalitesi ve Yerellik Yazıları (Writings on Daily Life, Quality of Life and Localism), Tarih Vakfi Yurt Publications, pp. 79-139, 2010.

[4] İnsan Hakları Evrensel Beyannamesi, (The Universal Declaration of Human Rights). (1948). [Online]. Available: http://www.ihd.org.tr/index.php/san-haklarylgeleri-mainmenu-96/156 -insan-haklari-evrensel-beyannames.html

[5] International Convenant on Civil and Political Rights, UN. (1966). [Online]. Available: https://treaties.un.org/doc/Publication/UNTS/Volume\%20999/volume -999-I-14668-English.pdf

[6] Environment And Development, Rio De Janeiro. (3-14 June 1992). [Online].

Available: http://www.un.org/documents/ga/conf151/aconf15126-3annex3.htm

[7] Turkish National Environmental Action Plan, Turkish Planning Organisation (DPT) Ankara, 1998.

[8] Bütünleşik Kentsel Gelişme Stratejisi ve Eylem Planı Raporu 2010-2023 (The Report on Integrated Urban Develeopment Strategies and Action Plan 2010-2023). KENTGES, Ankara. (2010). [Online] Available: http://www.kentges.gov.tr/_dosyalar/kentges_tr.pdf

[9] H. C. Duman and T. V. Arslan, "Urban Applications Where The Destruction Of Cultural Origanility - Uniformification Process Of Toki Case, Re- Invention of City Center," in Proc. $26^{\text {th }}$ International Building and Life Congress, Proceeding Book, Bursa, April 2014, pp. 91-97.

[10] TOKI Housing Program Photo Gallery. [Online]. Available: https://www.toki.gov.tr/

[11] TOKI Housing Program Photo Gallery. [Online]. Available: http://www.kaldirimoglugrup.com.tr/toki-eskisehir-odunpazari-3-etap/

[12] TOKİ. (April 2014). 288 housing units are to be built by TOKİ in Sivas İmranl. [Online] Available: http://emlakkulisi.com/toki-sivas-imranlida-288-adet-konut-yaptiraca $\mathrm{k} / 246818$

[13] TOKI Projects. [Online]. Available: http://www.tokikonutlari.net/bursa-gursu-toki

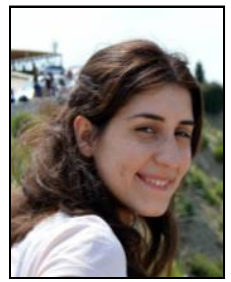

Hatice Ceren Duman was born in Diyarbakır in 1987 and she graduated from Architecture Faculty of Dokuz Eylül University in 2011. She is a master degree in education historical architecture at Uludağ University in Bursa. In 2011 she worked as a supervising engineer in Diyarbakır. She had beenresponsible for 1024 residence, social facility in terms of "General infrastucture, residence infrastructure and Landscaping". Then between the years of 2012-2013, she had an experience in two architecture offices. Now Ms. Duman is working as a research assistant in Uludağ University Architectural Faculty .

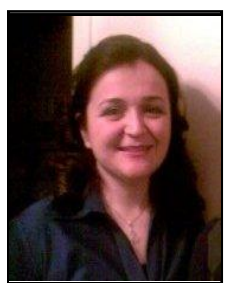

Tulin Vural Arslan was born in Bursa in 1974. She completed her bachelor degree of architecture in Middle East Technical University in 1996, and finished master degree in Middle East Technical University, Faculty of Architecture in 1999 and $\mathrm{PhD}$ in Istanbul Technical University, Faculty of Architecture in 2005. She has been an architect for eighteen years in Turkey. Now she is working as an associate professor in Uludağ University Faculty of Architecture. Her field of interest is architectural design, design of commercial areas and cultural heritage. 